Aletria, Belo Horizonte, v. 30, n. 3, p. 227-230, 2020

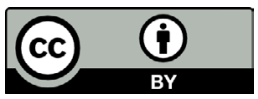

\title{
OLIVEIRA, Solange Ribeiro de. Alvoroço da criação: a arte na ficção de Clarice Lispector. Belo Horizonte: Editora UFMG, 2020.
}

\author{
Camila Augusta Pires de Figueiredo \\ Universidade Federal de Minas Gerais (UFMG), Belo Horizonte, Minas Gerais / Brasil \\ camilafig1@gmail.com \\ https://orcid.org/0000-0002-0522-8114
}

\begin{abstract}
"[...] uma arte? Sim [...] um artifício por meio do qual surge uma realidade delicadíssima que passa a existir em mim: a transfiguração me aconteceu".
\end{abstract}

Clarice Lispector, Água viva.

Neste ano que marca o centenário do nascimento de Clarice Lispector, a Editora UFMG publica Alvoroço da criação, obra que discute a relação da ficção da autora com as artes visuais, em especial a pintura, a escultura, a arquitetura, as artes decorativas e a natureza-morta. A convergência entre as artes estabelece o pano de fundo que abriga os pontos cruciais de sua escrita: os temas existenciais e a condição da mulher, localizada em uma longa tradição ecfrástica feminina que será abordada no volume.

A obra é apresentada brevemente por Fábio Lucas (escritor e crítico literário, vencedor do Prêmio Jabuti e membro da Academia Mineira de Letras), que enaltece as cuidadosas análises realizadas por Solange Ribeiro de Oliveira, que "apanham e seduzem o leitor" e oferecem um "agudo e inteligente tratamento investigativo" (LUCAS, 2020, p. 11), algo raro entre os aparatos avaliativos do conjunto de obras da ficcionista brasileira. 
Professora emérita da Universidade Federal de Minas Gerais e autora de diversos títulos sobre literatura e outras artes - entre eles $A$ barata e a crisálida: o romance de Clarice Lispector (1985), Literatura e música: modulações pós-coloniais (2002), Literatura e música (2003) e Perdida entre signos: literatura, artes e mídias, hoje (2012)-, Solange Ribeiro de Oliveira introduz Alvoroço a partir da tese de que na ficção de Lispector as alusões aos elementos pictóricos se configuram como metáforas de uma temática existencial, e também moldam a interpretação dos personagens (muitos deles artistas) e as vozes narrativas que compõem a sua construção textual.

Abundam no conjunto da ficção clariceana os iconotextos, formas híbridas em que imagens visuais - que não precisam necessariamente se referir a obras de arte conhecidas ou reais - são materializadas pela construção verbal, como as detalhadas descrições da luminária no início e no fim de $O$ lustre. A fim de identificar as outras formas artísticas presentes nos romances, Solange Oliveira recorre à escala tipológica de Liliane Louvel (2012), que considera os graus de saturação em diversos fenômenos, estabelecendo uma ordem crescente de picturalidade: o efeito quadro, a vista pitoresca, a hipotipose, os quadros vivos, o arranjo estético, a descrição pictural e, por fim, a écfrase.

$\mathrm{O}$ efeito quadro, por exemplo, ocorre quando o leitor tem a impressão - normalmente derivada da utilização de marcadores lexicais como cores, perspectivas, formas, linhas - de ver um quadro ou um gênero pictural. No polo oposto da gradação, está a écfrase, a verbalização de configurações visuais estáticas por meio da descrição textual.

Ao longo de sete capítulos, Solange Oliveira aborda os fenômenos picturais presentes em nove romances de Clarice publicados entre 1943 e 1977, a dizer: Perto do coração selvagem (1943), O lustre (1946), A cidade sitiada (1949), Laços de família (1960), A legião estrangeira (1964), A paixão segundo G.H. (1964), Uma aprendizagem ou O livro dos prazeres (1969), Água viva (1973) e A hora da estrela (1977).

O primeiro capítulo dedica-se à análise de Perto do coração selvagem e menciona em especial a descrição efeito quadro de Joana entrando no banho, nas primeiras páginas, e a descrição ecfrástica de uma paisagem marinha, ao final do livro. Nessas duas passagens, Solange afirma, a picturalidade serve ora como um prenúncio dramático das transformações na vida da protagonista, ora como uma ferramenta 
de rememoração das experiências sofridas quando jovem. A autora estabelece um paralelo entre o primeiro trecho e a pintura de Ticiano, Venus Anadyomene, e entre o segundo e Sailboats near Trouville, de Eugène Boudin, figuras que se encontram em um caderno impresso em cor, localizado no início do livro, em meio a um conjunto de 13 outras imagens que auxiliarão os leitores a acompanharem os diversos exemplos mencionados pela autora.

O segundo capítulo aborda a descrição de espaços interiores, a casa e seus objetos decorativos, como o casarão de propriedade da avó de Virgínia e sua sala de jantar, de cujo teto pende um grande lustre. Solange recorre ao conceito de topoanálise, de Gaston Bachelard (1964), que promove um estudo psicológico dos espaços habitados, e a outros estudiosos que tratam dos significados da arte decorativa para compreender a relevância do lustre na obra.

A cidade sitiada é tema do terceiro capítulo, momento em que a autora se dedica ao exame da écfrase na descrição de uma estátua equestre, imagem que "desempenha múltiplas funções, desde a caracterização da personagem até a estruturação do texto e sua articulação com virtualmente toda a ficção da autora" (OLIVEIRA, 2000, p. 47). Destaca-se a imagem da mulher-centaura, figura emblemática metafórica do anseio da mulher pela liberdade, que vai se fazer presente em outros romances de Lispector.

Em A paixão segundo G.H., tema do capítulo 4, ressalta-se a estrutura de monólogo cíclico e o tema existencial, com o acréscimo das questões de gênero e de classes sociais. Do ponto de vista das artes relacionadas, Solange aponta o contraste entre a arte primitiva no painel do quarto e a arquitetura moderna do edifício onde mora G.H., bem como destaca a relevância da prática artística da protagonista.

Poema em formato de prosa, Água viva é objeto do capítulo seguinte. Ficção experimental, se comporta como um "abstracionismo literário", em que o foco não está na descrição de fatos e personagens, mas na própria palavra, em um frágil equilíbrio entre abstração e figuração. Entre as imagens evocadas, destaca-se a da delicada água-viva, que é examinada pela autora.

O penúltimo capítulo se dedica a $A$ hora da estrela, o último movimento de Clarice em direção ao figurativo, mais especificamente às esculturas da arte sacra popular brasileira, objeto de admiração do personagem Olímpico, que também faz caricaturas satíricas. Enfatizam- 
se aqui as questões sociais e políticas, de algum modo observadas em romances anteriores.

Solange Ribeiro finaliza a sequência de capítulos com uma análise conjunta de Laços de família, A legião estrangeira e Uma aprendizagem ou O livro dos prazeres e sua próxima relação com a natureza-morta ou still life, termo em inglês que, como lembra a autora, também carrega o significado de "vida imóvel" ou "vida silenciosa". À breve explicação desse gênero de pintura seguem os trechos dos romances que mencionam os peixes, as frutas e a mesa posta, juntamente com referências a telas de diversos pintores, de Paul Cézanne a Alfredo Volpi.

Ao concluir, a autora retoma o objetivo principal da obra, a análise dos romances de Lispector a partir de suas relações com as artes visuais, para realizar uma útil compilação dos principais pontos apresentados e para revelar as funções ou efeitos desse emprego do pictural.

Merece destaque a capacidade da autora de estabelecer conexões com obras e artistas em diversas mídias e das mais variadas épocas, das pinturas holandesas do século XVI às modernas videoperfomances, passeando com maestria por caminhos artísticos nem sempre óbvios e que conduzem o leitor a uma compreensão mais ampla da poética clariceana.

Como em todo o restante do livro, cabe destacar também nesta última parte a competência com que a autora relaciona as artes referenciadas e os pontos temáticos presentes nos romances. À luz da abordagem interartes proposta, compreende-se claramente o modo como a picturalidade presente em Lispector-embora às vezes em trechos bem curtos - exerce múltiplas e relevantes funções e acaba por atar as pontas das tramas narrativas com nós que não se desfazem facilmente.

Longe de aspirar a uma análise abrangente, Alvoroço da criação atende bem seu propósito de contribuir para a compreensão da poética pictural da centenária escritora. Destinada à legião de pesquisadores e admiradores de Lispector, a publicação de Solange Oliveira vem revelar o estimulante alvoroço de formas e práticas artísticas subjacentes à escrita clariceana, artifícios de uma delicada realidade que transfigura. 


\section{Referências}

BACHELARD, Gaston. The Poetics of Space. Trad. Maria Jolas. New York: The Orion Press, 1964.

LOUVEL, Liliane. Nuanças do pictural. Tradução de Márcia Arbex. In: DINIZ, Thaïs Flores Nogueira (org.). Intermidialidade e estudos interartes. Belo Horizonte: Editora UFMG, 2012. p. 47-69.

LUCAS, Fábio. Prefácio. In: OLIVEIRA, Solange Ribeiro de. Alvoroço da criação: a arte na ficção de Clarice Lispector. Belo Horizonte: Editora UFMG, 2020. p. 11-14.

OLIVEIRA, Solange Ribeiro de. Alvoroço da criação: a arte na ficção de Clarice Lispector. Belo Horizonte: Editora UFMG, 2020.

Recebido em: 28 de setembro de 2020.

Aprovado em: 2 de outubro de 2020. 